\title{
Olvasásra ajánljuk
}

\section{Suggested readings}

Kulcsszavak: integrált népegészségügyi szakpolitikák, pszichoaktív szerhasználat, szegregátum, koherenciaérzés, észlelt stressz, egyenlőtlenség, származó javak egyenlőbb elosztása

\section{Tartalom}

Ott vagyunk már? - Integrált Népegészségügyi Szakpolitikák koncepciójának operacionalizálása ... 77

Szerhasználat egy hátrányos helyzetű járás szegregátumaiban.... 78

A koherenciaérzés és az azt meghatározó tényezők vizsgálata kínai egyetemisták körében: keresztmetszeti kutatás 79

Evidenciák irodalmi áttekintése - Egyenrangúbb társadalmak teremtése Mi múködik? 80 


\title{
Ott vagyunk már? - Integrált Népegészségügyi Szakpolitikák koncepciójának operacionalizálása
}

\author{
Are we there yet? - Operationalizing the concept of Integrated Public Health Policies \\ Hendriks AM, Habraken J, Jansen MW, Gubbels JS, De Vries NK, van Oers H, Michie S, Atkins L, Kremers SP \\ Health Policy. 2014 Feb;114(2-3):174-82. 10.1016/j.healthpol.2013.10.004. Epub 2013 Oct 23.
}

\author{
Ismertető: Járomi Éva $\bowtie$ \\ Nemzeti Egészségfejlesztési Intézet
}

\section{ÖSSZEFOGLALÁS}

Jelen kormányzati törekvések az integrált népegészségügyi szakpolitikák létrehozásával egy egészségesebb társadalom elérését célozzák. Azonban nehéz megmondani, hogy melyek az „integráltnak" nevezhető szakpolitikák, mert ennek a meghatározásnak jelenleg nincs egységes, operatív definíciója. Csak néhány a számos kutatás megfogalmazásából: egészség minden szakpolitikában - health in all policies, multiszektoriális szakpolitikák - multi-sectoral policy, egészséges közpolitika - healthy public policy vagy teljes kormányzat - whole-of-government, teljes társadalom - whole-of-society, kormányzat az egészségért-governance for health.

Jelenleg nincs konkrét szempontrendszer a gyakorlati értékelésre, amely megmondja, hogy szakpolitikák milyen mértékben integráltak. A politikai folyamatok ugyanis gyakran nem lineárisak, hanem komplexek. A fejlesztők és a megvalósítók értékeinek versenyét, illetve annak eredményeit tükrözik. Jelen közleményben a korábbi operacionalizációk szakirodalmi áttekintését követően a korábbiak hiányosságainak azonosítása, valamint új célok kijelölése és megalkotása történt: a népegészségügyi szakpolitikák integrációjának fogalmi tisztázása, operacionalizálása.

\begin{abstract}
A szerzők az alábbi kritériumokat fogalmazták meg: a szakpolitikák kombinálását; a beavatkozások mixét, amely optimalizálja a viselkedési rendszer funkcióit (motiváció, képesség, lehetőség); az egészségügyi szektor proaktivitását; valamint a különböző szakpolitikák (vagy azok kombinációinak) területén és annak fejlesztésében történő együttműködését. A viselkedésváltoztatás kerekének modelljét/keretrendszerét megfelelőnek találták a komplexitás és integrált szakpolitikák szemléltetésére. A modell előnyei: a politikai kategóriák és beavatkozási funkciók kombinációja, különböző szektorok együttmúködése, számos eszköz rendelkezésre állása, rendszerszemlélet. A modell, szerzők által megfogalmazott gyengeségei: számos készség és idő szükséges a megfelelő beavatkozás megtalálásához; nincs specifikus iránymutatás a megfelelő intézkedés kiválasztásához, valamint nem garantálható az intézkedések sikere.
\end{abstract}

Következtetések: a fenti kritérium alapján monitorozható és irányítható az integrált népegészségügyi szakpolitika, amely párbeszédet, vitát stimulálhat a szakpolitikákban.

\section{KULCSÜZENET A SZAKEMBEREK SZÁMÁRA}

A hazai népegészségügyi szakpolitikák tervezésénél a fenti kritériumok figyelembevételére és alkalmazására kell törekednünk. 


\title{
Szerhasználat egy hátrányos helyzetű járás szegregátumaiban
}

\author{
Substance use in the segregated areas of a disadvantaged district \\ Szécsi Judit, Sik Dorka \\ Esély 2016/2, 115-131. old
}

Ismertető: Nyírády Adrienn $\square$

Nemzeti Egészségfejlesztési Intézet

\section{ÖSSZEFOGLALÁS}

2015 nyarán terepkutatás készült az észak-alföldi régió egyik járásában, három kiválasztott település szegregátumaiban, a mélyszegénységben élők droghasználati mintázatainak feltárását célozva, különös tekintettel az újfajta pszichoaktív szerhasználatra. Az eredmények az mutatják, hogy az idősebb generáció az alkohol és cigaretta mellett gyógyszereket fogyaszt visszaélésszerúen, míg a fiatalok, egészen korai időszaktól inkább az új pszichoaktív szereket (szintetikus kannabinoidokat) használják. A szintetikus kannabinoidokról azt mondják, hogy olcsó, gyorsabban és intenzívebben hat, könnyű hozzáférni és legálisnak vélik. A szerválasztás indokaként a klasszikus okokat sorolták fel: elfelejtik a problémákat, csökkenti a magányérzést, menő, unalomúző.

A drogokkal és a függőség természetével kapcsolatos minden tudás és áltudás, illetve tudatlanság meglehetősen kollektív. A szerfogyasztás a gyerekek előtt zajlik, akik ismerik a szerek neveit, részletesen el tudják mesélni, hogyan néznek ki, hogyan használják, és milyen hatást váltanak ki. A szülők tudják, hogy drogoznak a gyerekeik. Az iskolában a tanárok is egyértelműen ismerik az egyes diákok szerhasználati szokásait, sőt az iskolai fogyasztással is tisztában vannak. Ezekben a közösségekben nem maradhat titokban semmi, de eszközük nincs a helyzet megoldására, javítására.

\section{KULCSÜZENET A SZAKEMBEREK SZÁMÁRA}

Soha nem volt még annyira aktuális a droghasználat társadalmi kontextusának hangsúlyozása, mint a szegregátumban élő, alsó társadalmi réteghez tartozó emberek esetében. A több generáción átívelő magas arányú munkanélküliség, a kilátástalanság következménye az elvágyódás, ennek azonban nincs realitása, ami tovább növeli a frusztrációt, amelynek „tompítása” gyakorta droghasználattal történik. A szegénység és nélkülözés, a kilátástalanság, valamint a kitaszítottság érzése az itt élő emberek lelki és fizikai egészségét is felemészti. 


\section{A koherenciaérzés és az azt meghatározó tényezők vizsgálata kínai egyete- misták körében: keresztmetszeti kutatás}

Sense of coherence and associated factors among university students in China: cross-sectional evidence Janet Junqing Chu, Mobarak Hossain Khan, Heiko J.Jahn, Alexander Kraemer

BMC Public Health (2016) 16:336

Ismertető: $\quad$ Kis Nóra $\square$

Nemzeti Egészségfejlesztési Intézet

\section{ÖSSZEFOGLALÁS}

A koherenciaérzés segít megoldani a konfliktusokat és megbirkózni a mindennapi, az egyént óhatatlanul érő stresszel. A salutogenezisi modell alapján az egészséghez erős koherenciaérzésre van szükség, és a jó egészségi állapot fejleszteni tudja az általános ellenállást, ami pedig a koherenciaérzést erősíti, tehát ez a visszacsatoló rendszer jelentős hatással bír a személy mentális egészségére. A koherenciaérzés és az egészség közötti kapcsolatot korábbi kutatások is alátámasztják. Antonovsky gondolatai alapján minden alkalommal, mikor a stresszel való sikeres megbirkózást tapasztal az egyén, erősíti a koherenciaérzés fejlődését.

A kutatás hipotézisei között szerepelt annak feltárása, hogy magasabb észlelt stressz szint alacsonyabb koherenciaérzéssel jár, míg a stresszel szembeni általános ellenállás magas koherenciaérzéssel párosul. Az adatokat két kínai egyetem diákjaival vették fel. A koherenciaérzést a Leipzig Short Scale alapján mérték. Az észlelt stresszt Cohen 14 tételes
Észlelt Stressz Skálájával vizsgálták. Életstílussal kapcsolatos változók voltak: a testmozgás gyakorisága, a saját egészségi állapot ismerete, a táplálkozás fontossága, testtömeg-index, és a saját testsúllyal való elégedettség. Azoknak a diákoknak, akiknek magas volt az egészségtudatosságuk, többet edzettek és elégedettebbek voltak a súlyukkal, erősebb volt a koherenciaérzésük. Az önmaguk által jobbnak ítélt tanulási teljesítmény társaikhoz képest, a jó kapcsolat a diáktársakkal, az egyetemen nem jelenlévő elszigeteltség érzés és a fennálló politikai helyzettel való elégedettség szintén kapcsolódott az erősebb koherenciaérzéshez. A megelőző szemlélet, mint a magas egészségtudatosság, és a táplálkozásra való nagyobb odafigyelés is összefüggött a koherenciaérzéssel. A társakénál jobb teljesítmény és a jó szubjektív egészség pozitív, míg az észlelt stressz erős negatív hatással van a koherenciaérzésre.

\section{KULCSÜZENET A SZAKEMBEREK SZÁMÁRA}

A koherenciaérzés fejlődésében kulcsfontosságú a támogató környezet.

A koherenciaérzés (és ez által az egészség) növelhető, ha az iskolák a versenyhelyzetet teremtő környezetet támogatóvá és elfogadó légkörúvé alakítják.

A kortársak és a tanárok támogatása tinédzserkorban meghatározó jelentőségú, mivel ez nagyban segíti a koherenciaérzés kialakulását.

\footnotetext{
' A salutogenezis modellt Aaron Antonovsky orvos-szociológus írta le. A modell az egészségteremtő folyamatokra, az egészség feltételeire és annak eredetére helyezi a hangsúlyt. Antonovsky elgondolása szerint a koherenciaérzés minden olyan alkalom esetén fejlődik, amikor az egyén sikeres megküzdést tanúsít a stresszel szemben.

ii Leipzig Short Scale = ez a skála az Antonovsky 29 tételes Sense of Coherence skálájának, 9 tételes változata.
} 


\section{Evidenciák irodalmi áttekintése - Egyenrangúbb társadalmak teremtése Mi müködik?}

Evidence Review - Creating more equal societies

What works?

Abigail McKnight, Magali Duque, Mark A. Rucci

Európai Bizottság „Foglalkoztatás, szociális ügyek és társadalmi befogadás” szakterületének KE-01-16-508-EN-N katalógus számú kiadványa (2016. június 30.)

Ismertető: Solymosy József Bonifácz $\square$

Nemzeti Egészségfejlesztési Intézet

\section{ÖSSZEFOGLALÁS}

Nincs meggyőző bizonyíték sem arra, hogy az egyenlőtlenség csökkentése gátolja a (gazdasági) növekedést, sem pedig arra, hogy az egy före jutó növekedés (automatikusan) az egyenlőtlenség csökkenését eredményezi a piacgazdaságként múködő demokráciákban. Viszont, ezek a társadalmak nem alaptalanul fókuszálnak arra, hogy maximalizálják a jövőbeni növekedéséből származó javak egyenlőbb elosztásának esélyét, és érthető, keresik a módját annak, hogyan érhető el stratégiákkal az, hogy a történelem során felhalmozott javak újraelosztásra kerüljenek.

\section{KULCSÜZENET A SZAKEMBEREK SZÁMÁRA}

Tény, hogy nem kell félteni a piacgazdaságot az egyenlőség eszméjétől, mert senki nem lesz attól érezhetően szegényebb, hogy másoknak is annyi jut, mint neki.

Viszont, nem is elég passzívan bízni az egy főre számolt növekedés jótékony hatásában, mert az csak statisztikai adat, a valóságban nem osztódnak a javak egyenlően maguktól. Szakpolitikai feladat tehát, hogy a stratégiák segítsék a már meglevő javak elosztása egyenlőbb legyen. 